\title{
Institutional Drivers for Managers: A study on Training Adoption and its Impact on Social Enterprises Legitimacy and Performance in Pakistan
}

\author{
Mishal Mufti (Corresponding author) \\ School of Public Affairs, University of Science and Technology of China, China \\ E-mail: mishal.mufti90@gmail.com
}

Syed Jamal Shah

School of Management, Harbin Institute of Technology, Harbin, China.

E-mail: jimmikakakhail@hotmail.com

Peng Xiaobao

School of Public Affairs, University of Science and Technology of China, China E-mail: pxb19822@ustc.edu.cn

Asma Sarwar

School of Public Affairs, University of Science and Technology of China, China

E-mail: asmas@mail.ustc.edu.cn

\section{Mariya Razzaghian}

School of Management, Institute of Management Sciences Peshawar, Pakistan

E-mail:moorazz@hotmail.com

Imad ud din

School of Social Science, National University of Modern Languages, Islamabad, Pakistan

E-mail: Imad.amdy@gmail.com

Received: March 6, 2020

Accepted: April 20, 2020

Published: April 30, 2020

doi:10.5296/jebi.v7i1.16606

URL: http://dx.doi.org/10.5296/jebi.v7i1.16606

\begin{abstract}
BACKGROUND: Despite wide global attention to training programs in business organizations, research on training programs and their outcomes at the social enterprises in general is very limited. This study aims to explicate the drivers and effects of manager's training.
\end{abstract}


OBJECTIVE: Based on institutional theory, this research explores the reasons why social enterprises train their managers as well as how the legitimacy and performance improves in response to training.

METHODS: Our theoretically derived model is tested using survey data obtained from ninety-nine senior managers of social enterprises in Pakistan. Data was analyzed through Partial Least Square structural equation modeling method (PLS-SEM).

RESULTS: The results of analysis support the idea that training of managers is synergistically and interactively driven by institutional forces e.g. normative, mimetic and coercive pressures. These institutional pressures spur social enterprises and induce them to adopt training programs to enhance their external and internal legitimacy and improve their performance.

CONCLUSIONS: This research emphasizes the importance of institutional pressures in adopting training programs in social enterprises. In sum, the present study provides important insights for senior managers in social enterprises who seek to foster external and internal legitimacy and improve performance. This study makes important contribution to the literature by developing an empirical link between institutional pressures and social enterprises performance. This research reiterates finding in previous studies to show the significance of the institutional forces in adoption of certain practices e.g. training of managers, to monitor the outcomes of training and providing further explanation regarding effects of training on legitimacy and performance.

Keywords: Institutional Pressures, Training of Managers, Social Enterprise Performance, Legitimacy

\section{Introduction}

A social enterprise addresses unmet needs and tackles variety of other problems through social and economic arrangements (Austin, 2006; Dacin, Dacin, \& Tracey, 2011; Shaw \& de Bruin, 2013). Social enterprises provide product and services to solve problems (Cordery \& Sinclair, 2013) and creates social value (Battilana \& Lee, 2014; Doherty, Haugh, \& Lyon, 2014). It has been well established that diverse and inclusive skills are requisite to solve the wide range of problems faced by social enterprises e.g. balance of short term objectives, core social mission, job security, concerns of board of trustees, progress and creativity in providing solution to the problems. British Council published a report in 2016 indicated challenges and barriers faced by Pakistani social enterprises e.g. supports, financial issues and weak formal training. Evidently, to achieve better performance, it is required to pay attention to the training of current staff in social enterprises. Most of research on social enterprise focuses on demonstrating the intention of youth towards social entrepreneurship. However, it is of equal importance to enhance the current social enterprise's standards to solve problems in better way to enhance overall performance. Besides others challenges, social enterprise managers faces similar problems likewise the managers of other businesses and non-profits sectors. Previous studies have taken in account the institutional theory as their research framework for entrepreneurial intention, nevertheless according to author knowledge; 
none of studies have demonstrated the effects of institutional pressure in adoption of practice and behaviors in social enterprises. Preceding literature also indicates that there is significant room for improvement in the quality of management system in social enterprises (Lyon \& Ramsden, 2006). Moreover, there has been witnessed that training of managers is considered as of critical importance because the balance of both entrepreneurship and management skills are required to run organization effectively (Davidsson, 2005; Gupta, MacMillan, \& Surie, 2004). Numerous researchers have identified significance of individual competencies to the performance in business sector; similarly social enterprise manager's require skills and competencies. Several studies, for example (Bird, 1995; Boyatzis \& Saatcioglu, 2008; Boyatzis, Stubbs, \& Taylor, 2002) have been conducted to show, education and experience can help to develop both managerial and entrepreneurial skills. Kandola \& Fullerton (1998) highlighted training as an important means to achieve success, as there is a shortage of labour-market, the ability to enhance growth in sector can be achieved by training of current workforce. Training of managers is beneficial in social enterprises, as it results in development of entrepreneurial and managerial skills. Because both skills and competencies when combine together leads in attainment of goals of the organization (Amini, Arasti, \& Bagheri, 2018).

A growing body of literature has investigated the effects of training on venture's results and performance (Ahmad \& Schroeder, 2003; Ghebregiorgis \& Karsten, 2007; Huselid, Jackson, \& Schuler, 1997; Jerez Gómez, Céspedes Lorente, \& Valle Cabrera, 2004; Mabey, 2004; Nikandrou, Apospori, Panayotopoulou, Stavrou, \& Papalexandris, 2008; Vlachos, 2008). As a result of training the workforce has been under focus of researchers, as it provides access to people with unique skills and inimitable valuable knowledge (Barney, 1991) that makes them more entrepreneurial so that they can attain higher outcomes and eventually, improve organizational performance. Yet despite of importance, training programs have received little attention from the scholars in social entrepreneurship. Araujo (2006) also suggested that besides training of entire workforce manager's training is considered more related to organizational results, due to its strategic nature and produce more constructive outcomes. Although there exists uncertainty, with regard to the managers training and performance, however, it produces unique organizational potential that is intricate to copy or replace (Mabey, 2004), which makes the research of managers training predominantly significant.

Drawing upon institutional theory, this research shows that institutional pressures result in training of managers and this training effect on legitimacy and performance of social enterprise. The institutional theory posits that organizations having same environments or surroundings are susceptible to adopt alike behaviors, activities and structures (Shonk \& Bravo, 2010). Seeking and managing legitimacy are vital to all organizations and is a basic component of institutional theory. Usually, social enterprises have to deal with both social and commercial institutional forces (Battilana \& Dorado, 2010; Battilana \& Lee, 2014). To gain legitimacy social enterprises try to balance both social and economic institutional logic (Connolly \& Kelly, 2011; Defourny \& Nyssens, 2006). Legitimacy serves as an instrument to strengthen organizational reputation both externally and internally (Bitektine, 2011; Suddaby \& Greenwood, 2005). Grant (2008) has identified the external environment political reforms, 
legislation, socio-cultural norms. Previous researches have failed to empirically analyze both internal and external legitimacy, most of studies focus on the only internal social enterprises environment.

In particular, paucity of attention has been paid to examine institutional pressures and their effects on adoption of training programs and their relative contribution to development of legitimacy and improved performance in the context of social enterprises. Besides other challenges, social enterprises in Pakistan are in lack of trainings, which is perceived as an important mean for success of entrepreneurial organizations. In this research paper, it is presented that training as possible intervening aspect to improve legitimacy and performance. External and internal legitimacy improves when an organization trains its workforce, externally it results in acceptance in social circle, improve better relations with funding organizations and other social enterprises adopting same kind of training, internally it results in improving employee commitment, motivation and nurture workplace climate. Training leads to active performance of managers e.g. increasing donors, enhanced communication and understanding the need of peoples. It may assist to progress in products and services provided by social enterprises. Researchers recognize that implementing and developing training programs for their managers is of fundamental importance for improvement in performance (Butler, Ferris, \& Napier, 1991; Schuler \& Jackson, 1987; Yang \& Konrad, 2011). This study investigates an association of training of managers and legitimacy and performance, while suggesting that institutional pressure serves as reason for training managers in social enterprises. The framework of this study provides the institutional factors which social enterprises take into consideration while conducting training of managers. This research takes new approach by providing the enlightenment on conduct of training programs, which is beneficial in providing clarification to actors concerned for training activities.

This research sought to address the main questions which institutional pressures contribute to management of training, the influence of training on social enterprises legitimacy and performance, based on the principles of institutional theory. The study is divided into three sections. Section one contains the literature on institutional pressures, training of managers, legitimacy, performance and development of hypotheses to be verified. Section two is allocated to research methodology includes survey development and data analysis technique. In section three the research findings, conclusions to form recommendations, implementations and limitations are derived from whole study.

\section{Theory and Hypotheses Testing}

This study incorporates institutional perspective on the verge to identify the behavior of social enterprise towards training that has been neglected until now, including coercive, normative, and mimetic pressures exerted by governments, funding agencies, unions, professional contacts, and social expectations. The behavior of organizations is tailored according to the standards and values which are established by the environment in which they operate, to attain legitimacy and acceptance of different actors in the environment. Because approval from these actors assists the survival and success of organizations (Hofman, Li, Sun, \& Sun, 2019) (John W. Meyer \& Rowan, 1977). According to this perspective, social 


\section{Macrothink}

Journal of Entrepreneurship and Business Innovation

ISSN 2332-8851

2020, Vol. 7, No. 1

enterprises initiate the human resource practices e.g. training of managers can be considered as counter to coercive, normative, and mimetic pressures, which causes initiation of training programs. These training programs not only results in enhancement of external and internal legitimacy, but also facilitate the organization to improve its performance.

Institutional theory help in understanding the relation of organization and its environment investigating the features associated to gain legitimacy and survival of organization in environment in which it is embedded (Gonin, Besharov, \& Smith, 2013). It recognizes the effects of external norms, values and traditions that present social legitimacy to organization and also influences management decision (John W. Meyer \& Rowan, 1977). The institutional theory stresses that decisions taken by organization are not always results of their business choices (Paul J DiMaggio \& Powell, 1991; Scott, 2008). It provides an explanation that how organization is influenced by outside factors which are not under their control, when outside environment of an organization is highly structured, it affects the implementation and selection of strategies of organization, hence forms homogeneity among organizations (Paul J. DiMaggio \& Powell, 1983). According to Tolbert and Hall (2009) five paradigms give an understanding of environments and show that institutional environment is made or shaped by governments, professional associations and other leading organizations. Legitimacy is considered an asset through which an organization gains social acceptance and evaluation. It provides organization to add more resources (Bitektine, 2011; Zimmerman \& Zeitz, 2002) also acts as mean to add good external and internal reputation to organizations (Bitektine, 2011; Suddaby \& Greenwood, 2005). According to Israel Drori (2013) legitimacy is not only external endorsement but also internal responses should be considered equally important. Extant literature have discussed the challenges in gaining and maintaining of legitimacy of social enterprises (Battilana \& Dorado, 2010; Connolly \& Kelly, 2011; Defourny \& Nyssens, 2006; Doherty, et al., 2014; Kuosmanen, 2014; Pache \& Santos, 2010; Tracey, Phillips, \& Jarvis, 2011).

The summary of hypotheses is shown as below.

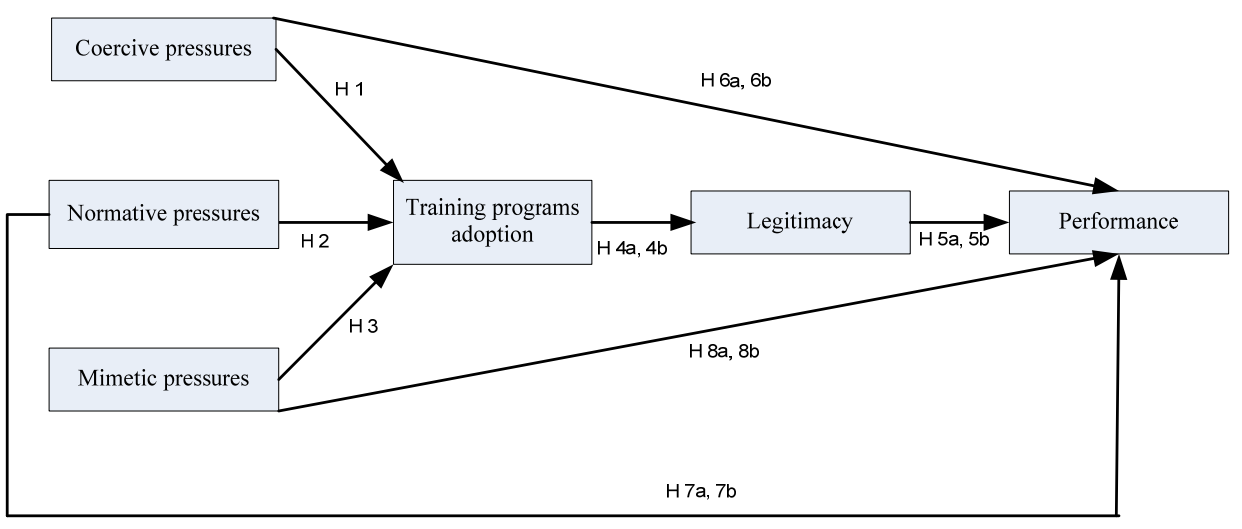

Figure 1. Summary of hypotheses 


\subsection{Coercive Pressures}

Institutional theory presents coercive pressures related to regulatory environment in which organization operates, usually established by government, funding organizations and unions (Scott, 2008). A coercive pressure usually comes from those entities or organizations to which organization is dependent. Several researchers have identified significant government influence on the behavior of an organization, even though when the regulations have no imposing violation penalties (Cashore \& Vertinsky, 2000; Dasgupta, Hettige, \& Wheeler, 2000; Khanna \& Damon, 1999). In case of social enterprise, although they are not obliged to implement training programs for managers or noncompliance will results in some punishment, but there exist coercive pressures from institutional actors such as funding organizations (government and non government), social agents and unions. Similarly, Booth el (2003) and Green (1999) have also identified the union influences on training program as there is an obligation to train their workforce, which is in favor of organization. In social enterprises case, they have to fulfill the requirements of these authoritative sources; noncompliance of requirement may result in funding issues, losing their legitimacy among union members. In developing countries such as Pakistan, local government and unions are recognized as an important means for developing reputation and easy access to funding for organizations. These coercive pressures result in compliance with regulations, and results in adoption of practices. According to Budhwar and Sparrow (2002) human resource management practices are result of legislative requirements, or by social allies e.g. unions (Paauwe, 2004). Likewise Comacchio and Scapolan, (2004) have shown adoption of e-learning systems, from the agreement between organization and union. It can be suggested that organizations run their training program to get accepted and consider legitimate among its social actors. We proposed hypothesis 1 :

H1: Coercive pressures arising from funding organizations and unions are positively related to the implementation of training programs for a manager in social enterprises.

\subsection{Normative Pressures}

Normative pressures consist of socially desired behaviors and norms on the organizations, to set standards that show how organization should respond (Scott, 2008). These standards usually come from professionalization and networks (Greenwood, Suddaby, \& Hinings, 2002; Martínez-Ferrero \& García-Sánchez, 2017). It is suggested that the professional associations and getting certification programs encourage setting foundation of certain norms, values and standards among its members and ensuing in legitimacy. Institutional norms may also guide the decision makers to mitigate the uncertainties of outcomes and help to adopt those practices and processes which will be beneficial to organization, thus avoiding uncertain situations. The association of professionals create standard practices for human resource management (Farndale \& Brewster, 2005), in case of present study, human resource practice is training of managers in social enterprises. Managers in an organization have networks and these networks result in connecting them to members of other organizations and it is also a source of developing norms among its members (Brandes, Hadani, \& Goranova, 2006; Guler, Guillén, \& Macpherson, 2002). This suggests that these associations and networks result in 
sharing of information, develop common beliefs, shared value and show inclination towards certain practices (AbouAssi \& Bies, 2018). As it has been verified for the implementation of quality systems (Westphal, Gulati, \& Shortell, 1997) or certain human resource practices (Pasamar Reyes \& Valle Cabrera, 2011). Consequently it can be concluded that more participation in different unions and networks results in establishment of certain standard behavior and practices (Som, 2007), such as training of managers. These arguments suggest the following hypothesis 2 :

H2: Normative pressures arising from professional associations are positively related to the implementation of training programs for managers of social enterprises.

\subsection{Mimetic Pressures}

Mimetic pressures arise when organization faces ambiguous environment or uncertain situations, they tend to follow the actions that are deemed to be an appropriate and already adopted by organizations perceived successful (Paul J. DiMaggio \& Powell, 1983). When social enterprises engages in training programs, other social enterprises will follow even if there exist lingering questions regarding the viability of training programs because decision-makers recognize that adopting social enterprises has developed benefits. Decision-makers imitate the actions of structurally equivalent organizations as considered successful in same field (Teo, Wei, \& Benbasat, 2003). Organizational mimetic behavior might be result of its social networks, organization tends to adopt successful practices (Palmer \& Biggart, 2002). The mimetic pressures result in the imitation of certain practices or behavior of other organizations to avoid uncertainty (Davidsson, 2005; Scott, 2008), as these practices or behaviors are considered valid and acceptable. These are pressures from cultural-cognitive domain, put organization into convergence with institutional environment. Whether an organization experience stronger or weaker pressures, the afterward response of organization to these pressures become mimic behavior and they start to follow the leader or prestige pioneers in their field for certain strategies or practices. To avoid uncertain situations, organizations follow the path of leaders who are considered legitimate in their field, intending to be considered as socially acceptable (Paauwe \& Boselie, 2003). Consequently, coping practices or behaviors of leading organization is considered as vital factor in determining behavior of organization (Delmas \& Toffel, 2004; Teo, et al., 2003) and selection related to human resource practices (Kostova \& Roth, 2002; Osterman, 1994; Pasamar Reyes \& Valle Cabrera, 2011). Subsequently it can be suggested that choice about the training of managers is made, this may be due to that organization follows their role models organizations (Combs, Michael, \& Castrogiovanni, 2009). It is anticipated that following the leaders will reduce the risk linked with the ambiguity of training managers without understanding if high-quality outcome will be achieved. Furthermore, the importance of most organizations in a specific sector give to particular practices or behavior, that elucidates and determine adoption (Brandes, et al., 2006; Honig \& Karlsson, 2004). These arguments suggest the following hypothesis 3:

H3: Mimetic pressures arising from uncertainty in the environment and monitor leaders in the sector are positively related to the implementation of training programs for managers in 
social enterprises.

\subsection{Management Training and External and Internal Legitimacy and Performance}

The effect of institutional pressures on adoption or implementation of training programs for managers give us an idea that as long as organizations are deemed as part of socially and culturally embedded in environment, they try to seek the acceptance of both social and culture (Paauwe \& Boselie, 2003). A considerable amount of literature has been published about organizations maintaining or managing legitimacy in conflicting demands from different institutional actors (Battilana \& Dorado, 2010; Kuosmanen, 2014; Pache \& Santos, 2010; Tracey, et al., 2011). Previous research suggested that obtaining legitimacy is of vital importance for social enterprises; as they have to maintain balance of economic and social responsibility (Connolly \& Kelly, 2011; Defourny \& Nyssens, 2006). In strategic management literature, it is recognized as necessary to survival and development of organization especially entrepreneurial organizations (Suddaby, Bitektine, \& Haack, 2017; Zimmerman \& Zeitz, 2002). Legitimacy is presented to organization from both external and internal actors in an environment of organization in which it is operating (Bitektine, 2011). The institutional environment usually involves regulative, normative, and cultural-cognitive factors, expecting certain institutional logics (Scott, 2013). Gaining legitimacy is not a magic formula; it requires the implementation of certain practices and behaviors. According to (Kostova \& Zaheer, 1999; Ruef \& Scott, 1998) sources of acceptance and approval of organization are divided into external and internal. Social enterprise confronts these different institutional actors and their legitimacy relies on approval of these actors. The funding organization, unions and professional linkages, opinion of people or public are included in external sources of approval or gaining legitimacy. On other hand managers, volunteers and shareholder are considered as internal sources of approval and gaining legitimacy. Social enterprises tend to attain both external and internal legitimacy by adopting human resource management practices e.g. training of managers. Literature supports the idea that gaining support from both external (Paul J DiMaggio \& Powell, 1991; John W Meyer, 1983; John W. Meyer \& Rowan, 1977) and internal stakeholders (Brown \& Toyoki, 2013; Drori \& Honig, 2013) is of critical importance for organizations.

From an institutional perspective, it is suggested that organization decide to train their managers to get accepted as legitimate. Frambach and Schillewaert (2002) have pointed out the vital role played by managers, as they perceive the outside environment and screens the information to make important decisions, which help organization to achieve its goals. Managers as resource play critical role, but managers in social enterprises often lack the experience which may hamper their ability to carry out entrepreneurial activities (Penrose \& Penrose, 2009). Managers in social enterprises must know how to monitor both social and commercial activities, social enterprise usually focus on unmet needs (Sud, VanSandt, \& Baugous, 2009) along with this they have to maintain the commercial activities, hence managers should have ability to handle the both in balance. It has been suggested by Lewis (2006) success of social enterprise depends on their leadership skill, business practices, management experience. Likewise, Barrett \& O'Connell (2001) insisted the critical importance of managerial efficiency. As in the past it has been reported, there exists fairly 
strong support that acting more entrepreneurially as a manager can have a considerable influence on both financial and attitudinal measures (Pearce, Fritz, \& Davis, 2010).

Morris (1993) has identified human resource practices e.g. training and development are necessary for entrepreneurial activity and an important tool for organizations to be successful. Implementing training programs is of critical importance, a broad range of skills are required for success (Kuzilwa, 2005; Lazear, 2004). Numerous studies have been conducted to show importance of human capital (general and specific) to show intention towards social entrepreneurship, but literature lacks in showing importance of human capital in success of social enterprises. In social enterprises investor demands better social change and also want economic returns (Mair \& Hehenberger, 2014), as a result social enterprises need to improve their performance to meet all the challenges. It is important for social enterprises to develop their manager's competencies (Kaufman, Avgar, \& Mirsky, 2007), to handle their operations in balance form, otherwise the donors and investors may perceive that their operations as only profit generating rather than serving society (Inoue \& Lee, 2011). These arguments suggest the following hypotheses.

H4a: The implementation of training programs for managers is positively related to the external legitimacy of social enterprise.

$\mathrm{H} 4 \mathrm{~b}$ : The implementation of training programs for managers is positively related to the internal legitimacy of social enterprise.

H5a: The external legitimacy gain by implementing training programs is positively related to performance.

H5b: The internal legitimacy gain by implementing training programs is positively related to performance.

H6a: Training of managers and external legitimacy will play a chain-mediating role in the relationship between coercive pressures and performance.

H6b: Training of managers and internal legitimacy will play a chain-mediating role in the relationship between coercive pressures and performance.

H7a: Training of managers and external legitimacy will play a chain-mediating role in the relationship between normative pressures and performance.

$\mathrm{H} 7 \mathrm{~b}$ : Training of managers and internal legitimacy will play a chain-mediating role in the relationship between normative pressures and performance.

H8a: Training of managers and external legitimacy will play a chain-mediating role in the relationship between mimetic pressures and performance.

H8b: Training of managers and internal legitimacy will play a chain-mediating role in the relationship between mimetic pressures and performance. 


\section{Macrothink

\section{Research Design and Methodology}

\subsection{Measures}

The survey was conducted to collect data on variables e.g. institutional pressures, training of managers (TOM), external legitimacy (EL), internal legitimacy (IL) and performance(PR). We have conducted research on both registered and unregistered social enterprises, because most social enterprises operates in Pakistan are informal and not registered. A five-point Likert scale ranging from 'strongly agrees' to 'strongly disagree' was used to assess the responses. The selected constructs are adapted from the formally preceding validated instruments. In this study institutional pressures on owners or senior managers are supposed to be a multidimensional scale, similarly to the scale of coercive pressures which is adapted from (Khalifa \& Davison, 2006; Teo, et al., 2003). The measurement scale for normative and mimetic pressures is adapted from (Esteban-Lloret, Aragón-Sánchez, \& Carrasco-Hernández, 2018). Training of managers is measured by number or percentage of managers trained. Those factors which contribute to or are source of legitimacy to the organization have been adapted from (Esteban-Lloret, et al., 2018). These different items to measure legitimacy have been used by (Certo \& Hodge, 2007; Dacin, Oliver, \& Roy, 2007; Kostova \& Zaheer, 1999; Scott, 2013; Thomas, 2005). Performance measurement has been adopted from (Liu, Eng, \& Takeda, 2015). Consistent with previous literature, this study use age and size of social enterprise as control variables (Pearce, et al., 2010). Organizational age is measured by number of years of operation and size as it can be naturally indicated by number of employee (Kreiser, Marino, Dickson, \& Weaver, 2010). Size of enterprise is considered 'small' if the number of staff falls below a specific limit (e.g. five employees) which is determined nationally (Hussmanns, 2004; ILO, 2011). These demographic variables (size and age of social enterprises) are important because it can affect the organization perception of environment. As large organization give more importance to their social and cultural environment. It is indicated age and size of organizations are standard variables and may have an impact on performance due to difference in environmental and organizational characteristics (Davis, Marino, Aaron, \& Tolbert, 2011; Wiklund \& Shepherd, 2005). The table 1 illustrates the constructs and sources. 


\section{Macrothink}

Table 1. Constructs and key sources used in questionnaire development

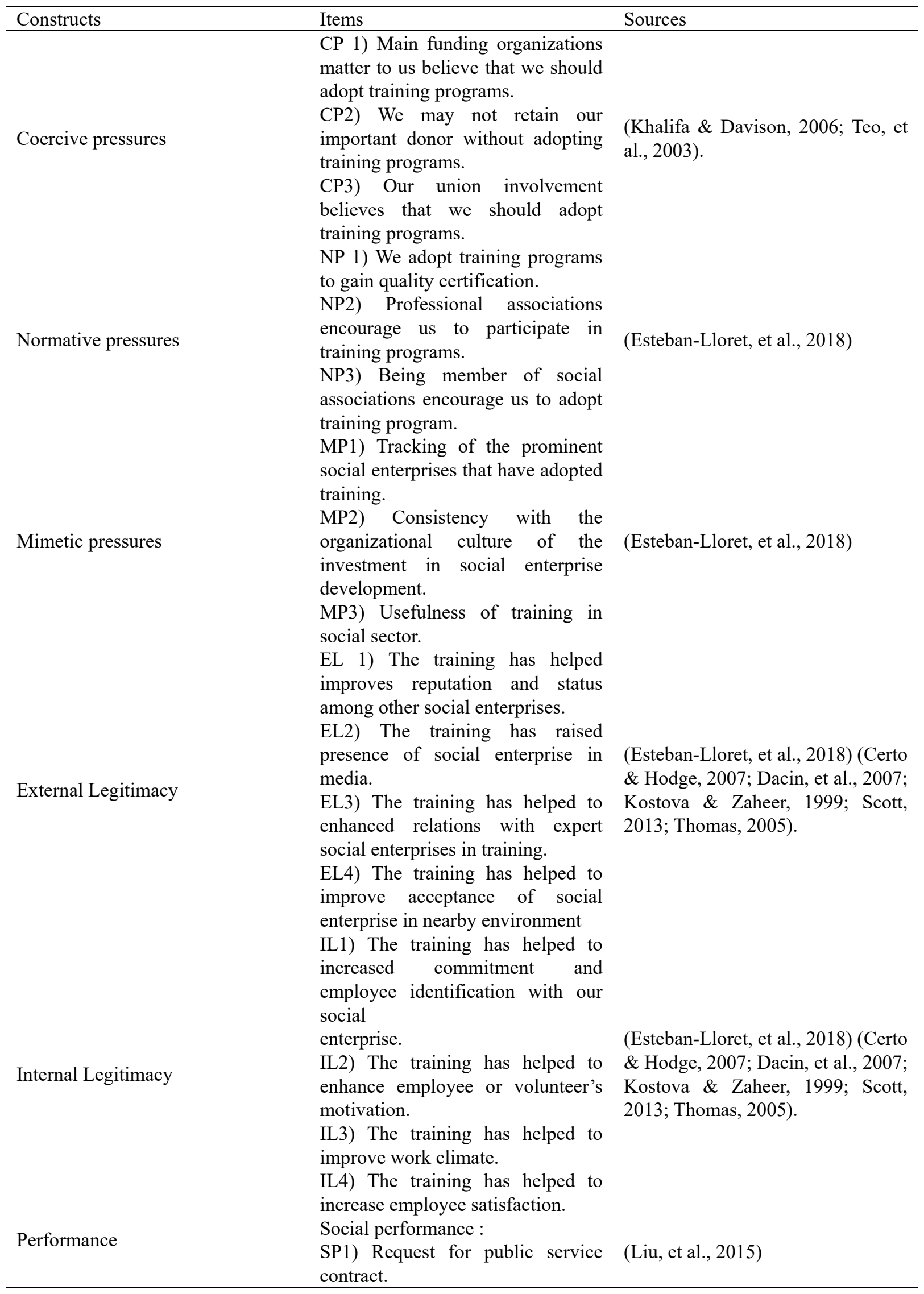




\begin{abstract}
SP2) Bidding funding body's for
grants for enterprise operations.

SP3) Serves more beneficiaries in the society.

SP4) Provide different types social services.
\end{abstract}

Economic performance:

EP5) Increased business unit profitability.

EP6) Attainment of enterprise

financial goals.

EP7) Social enterprise customer

satisfaction.

EP8) Delivering value to your

social enterprise customer.

EP9) Spread out enterprise activities to different locations.

\title{
3.2 Analytical Procedure
}

As the data was obtained from the individual participants in a cross-sectional study, there was concern for potential for Common Method Variance (CMV) (Spector et al., 2006). To assess CMV, Harman's one-factor test was carried out (Podsakoff, MacKenzie, Lee, \& Podsakoff, 2003). During this test, the entire principal constructs are entered into a principal components factor analysis. Verification of CMV exists when a single factor appears from the analysis or when one general factor accounts or responsible for the majority of the covariance in the interdependent and dependent variables. The results showed that seven factors based on eigen value in excess of 1 , accounted for $66.5 \%$ variance, while the highest single factor, representing $\mathrm{CP}$, accounting for $24.9 \%$ of the variance. This indicates that CMV does not appear to be a substantial issue in the data of this study.

The study employed Smart PLS 3 software, and the hypothesized model was tested using Partial Least Square Method for structural equation modeling (PLS-SEM). PLS-SEM is the technique developed as an alternative to traditional structural equation modeling that is covariance-based (CB-SEM), and emphasizes perdition while simultaneously relaxing the demands on data and specification of relationships (Huang, 2017). One of the vital property of PLS-SEM is that it facilitate to calculate the path models with small sample with data from highly skewed distribution (Al-Dhaafri Hassan, 2016). Since the size of the sample in the current study is 99 , which is considered comparatively low when compared to the complexity of the model under investigation. Therefore, PLS-SEM was an appropriate choice to get the analysis done and the objective of the study accomplished.

\section{Results}

\subsection{Measurement Model Evaluation}

To ascertain the validity and reliability of constructs, individual item reliability, convergent validity, and discriminant validity were measured (J.F. Hair, Hult, Ringle, \& Sarstedt, 2016). 


\section{Macrothink}

All of these coefficients exceeded the recommended thresholds (i.e. Cronbach $\alpha>0.60$ ) thus accepting the reliability of the measures used (Kline, 2015). To establish or ascertain the convergent validity, the average variance extracted (AVE) for each latent factor was evaluated. In general, the AVE values larger than the essential minimum of 0.5 provide support for convergent validity (Fornell \& Larcker, 1981). As shown in Table 2, AVE values were higher than the recommended threshold, hence, indicating satisfactory convergent validity. For valid discriminant of a construct, the square root of each construct's AVE should be higher than its correlations with other constructs (Fornell \& Larcker, 1981; Shah et al., 2018). The results depicted in Table 2 satisfied the said criterion confirming measurement model has the required discriminant validity.

Table 2. Mean, standard deviation, validity, and correlation

\begin{tabular}{ccccccccccccc}
\hline Variable & C $\alpha$ & & AVE & $M$ & SD & CP & MP & NP & TOM & IL & EL & PR \\
\hline CP & 0.77 & 0.67 & 3.2 & 1.03 & 1 & & & & & \\
MP & 0.88 & 0.80 & 3.1 & 1.17 & -0.07 & 1 & & & & \\
NP & 0.84 & 0.76 & 3.2 & 1.20 & 0.12 & 0.09 & 1 & & & \\
TOM & 1.00 & 1.00 & 3.2 & 1.50 & $0.24^{*}$ & $0.21^{*}$ & $0.27^{* *}$ & 1 & & \\
IL & 0.86 & 0.71 & 2.8 & 1.08 & 0.07 & 0.08 & 0.11 & $0.23^{*}$ & 1 & \\
EL & 0.83 & 0.66 & 2.9 & 1.01 & 0.07 & 0.13 & 0.08 & $0.28^{* *}$ & $0.19^{*}$ & 1 \\
PR & 0.94 & 0.67 & 2.7 & 1.08 & -0.08 & -0.12 & 0.09 & 0.009 & $0.28^{* *}$ & $0.28^{* *}$ & 1 \\
\hline
\end{tabular}

Note: $* * \mathrm{p}<0.01$ (Two-tailed)

AVE Average variance extracted, Cronbach Alpha, CP: Coercive Pressure, EL: External Legitimacy, IL: Internal Legitimacy, M: Mean, MP: Mimetic Pressure, NP: Normative Pressure, PR Performance, SD: Standard Deviation, TOM: Training of Manager.

\subsection{PLS-SEM Evaluation}

Having established the reliability and validity of the measurement model, author move to subsequent part that was the evaluation of structural model (Joseph F Hair, Ringle, \& Sarstedt, 2013) that would test the model's predictive capabilities and the relationship and connection involving given constructs. Based on analysis criteria recommended by (Henseler, 2009) three logical metrics were applied to judge or evaluate the structural model, the significance of path coefficients, coefficient of determination $\left(R^{2}\right)$, and the cross-validated redundancy $\left(Q^{2}\right)$. Accordingly, the PLS algorithm procedure was performed to find estimates for the structural model relationships (the path coefficients) and analyze the hypothesized association between constructs. Besides, PLS algorithm procedures, we evaluated the significance of 
associations by conducting a bootstrapping algorithm (using 5000 resample). Note, the control variables used in this research do not demonstrate considerable effects and are thus not reported.

Hypothesis 1, which expects that coercive pressure encourage the implementation of training programs for managers in social enterprises, was supported with path coefficient $\beta=0.25$, standard error $\mathrm{SE}=0.18$, t-statistics $t=3.07$, at significance level $P<01$. Hypothesis 2 also received full support, as normative pressures was found positively linked with training programs implementation $(\beta=0.22, \mathrm{SE}=0.14, t=2.49, p<0.05)$. Hypothesis 3 , which proposes the positive relationship between mimetic pressures and implementation of training programs for social enterprises managers, was also accepted $(\beta=0.22, \mathrm{SE}=0.13, t=2.42, p<0.05)$. Similarly, the direct link between training program implementation and external legitimacy was found significant $(\beta=0.30, \mathrm{SE}=0.06, t=3.09, p<0.01)$. At the same time, the training program implementation was positively and significantly influencing internal legitimacy $(\beta=0.23, \mathrm{SE}=0.07, t=2.36, p<0.05)$. Thus, Hypotheses $4 \mathrm{a}$ and $4 \mathrm{~b}$ were also supported. The hypothesized direct relationships of external $(\beta=0.24$, SE $=0.12, t=2.44, p<0.05)$ as well as internal $(\beta=0.24, \mathrm{SE}=0.13, t=2.42, p<0.05)$ legitimacy with performance were found significant, thereby leading to the acceptance of Hypotheses $5 \mathrm{a}$ and $5 \mathrm{~b}$.

As suggested by (Joseph F Hair, Hult, Ringle, Sarstedt, \& Thiele, 2017) iterations of the bootstrapping method were used to estimate $95 \%$ confidence interval using 5000 subsample for the indirect effect (Preacher \& Hayes, 2008). In this method, the indirect effect from each subsample is calculated, which directs to the computation of an overall confidence interval (CI). If zero is not in the interval, then the researcher can presume that the indirect effect is different from zero and significant (Borst, Kruyen, \& Lako, 2017).

$H 6 a$ and $H 6 b$ were supported, as results revealed that coercive pressure had a significantly positive effect on performance through chain mediators TOM-EL (Estimate $=0.017, S E=0.01$, 95\% CI $=[0.002,0.058]$ ), and TOM-IL (Estimate $=0.021, S E=0.01,95 \% \mathrm{CI}=[0.004,0.066])$. Similarly, chain-mediating effects of TOM-EL (Estimate $=0.020, S E=0.01,95 \% \mathrm{CI}=[0.003$, 0.065]) and TOM-IL (Estimate $=0.015, S E=0.01,95 \% \mathrm{CI}=[0.001,0.049]$ ) were also established between the association of normative pressure and performance, supported $\mathrm{HTa}$ and $H 7 b$. Finally, results were consistent with proposition that mimetic pressure have significant indirect effect on performance via TOM-EL (Estimate $=0.016, S E=0.01,95 \% \mathrm{CI}=$ $[0.001,0.058])$ and TOM-IL (Estimate $=0.013, S E=0.01,95 \% \mathrm{CI}=[0.001,0.046])$, led us to the acceptance of $H 8 a$ and $H 8 b$.

In addition, the $R^{2}$ values of endogenous latent constructs were also estimated from PLS algorithm as illustrated in Figure 2. The $R^{2}$ value for endogenous variables were found elevated high and medium predictive accuracy degree as training of managers $=0.17$, legitimacy (external $=0.09$, internal $=0.05$ ), performance $=0.14$. Subsequent to the assessment of $R^{2}$ values as a criterion of predictive accuracy, we examined the $\mathrm{Q}^{2}$ value that indicates the model's predictive relevancy. The $\mathrm{Q}^{2}$ measure use a resample technique that excludes part of the data matrix and uses the model estimates to calculate the omitted part. $\mathrm{Q}^{2}$ values of $\mathrm{TOM}=0.10, \mathrm{EL}=0.04, \mathrm{IL}=0.30$, and $\mathrm{PR}=0.08$ specify that an exogenous construct 


\section{Macrothink}

has a small, medium or large predictive relevance for a chosen endogenous construct. Furthermore, Table 3 shows the $f^{2}$ effect size as indicator of the impact of a specific predictor construct (exogenous construct) on endogenous constructs (Rezaei, Shahijan, Valaei, Rahimi, \& Ismail, 2016). The $f^{2}$ effect size depicts the change in the $R^{2}$ value when a specified exogenous construct is dropped from the entire or complete model $f^{2}$ values of $0.07,0.06$, $0.06,0.05,0.06,0.10$ and 0.05 indicate a small, medium or large effect.

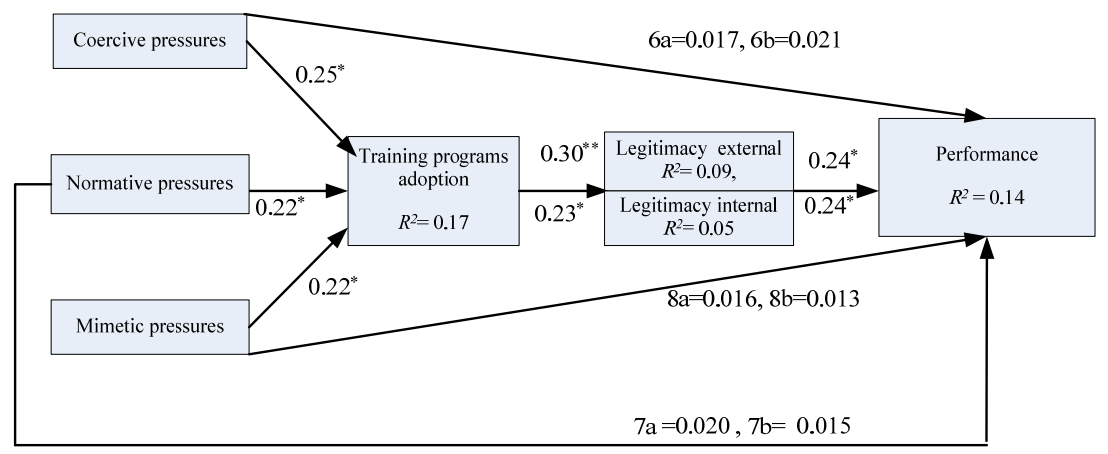

Figure 2. Path coefficients, coefficient of determination $\left(\mathrm{R}^{2}\right)$, Estimate

Notes. $* \mathrm{p}<0.05 ; * * \mathrm{p}<0.01$, for testing chain mediation Estimate is given shown in hypotheses $6 \mathrm{a}, 6 \mathrm{~b}, 7 \mathrm{a}, 7 \mathrm{~b}, 8 \mathrm{a}, 8 \mathrm{~b}$.

Table 3. Hypotheses testing results

\begin{tabular}{|c|c|c|}
\hline Path & $\beta$ & $f^{2}$ \\
\hline Training of managers $\leftarrow$ Coercive Pressure & $0.25^{*}$ & 0.07 \\
\hline Training of managers $\leftarrow$ Normative Pressure & $0.22^{*}$ & 0.06 \\
\hline Training of managers $\leftarrow$ Mimetic Pressure & $0.22^{*}$ & 0.05 \\
\hline External Legitimacy $\leftarrow$ Training of managers & $0.30^{* *}$ & 0.10 \\
\hline Internal Legitimacy $\leftarrow$ Training of managers & $0.23^{*}$ & 0.05 \\
\hline Performance $\leftarrow$ External Legitimacy & $0.24^{*}$ & 0.06 \\
\hline Performance $\leftarrow$ Internal Legitimacy & $0.24^{*}$ & 0.06 \\
\hline
\end{tabular}

Notes $={ }^{*} \mathrm{p}<0.05 ; * * \mathrm{p}<0.01$

\section{Discussion and Conclusion}

The current study proposed a model that takes the institutional pressures as means for adoption of practice e.g. training of managers for enhancement of legitimacy and performance. As (Kibler, Salmivaara, Stenholm, \& Terjesen, 2018) carried out, study related to legitimacy of social enterprises in capitalist warfare, and call for study legitimacy at individual level and stated that national and local institutions may enhance legitimacy. This study enhances literature by incorporating institutional theory to improve the understanding of training programs adoption and their effect on performance and legitimacy. This research raised the two important research questions. The first question is what are the main institutional pressures that contribute to adoption of training programs in social enterprises in Pakistan? Second, how training programs add to enhancement and advancement of 
legitimacy and performance of social enterprises?

This study explored institutional influences on adoption of training programs and effects of these programs on legitimacy and performance of social enterprises. This study addresses those factors which have not been taken into account so far, our research includes institutional factors in explaining the adoption of training programs and the outcomes are in the form of legitimacy and better performance. Since we consider adoption of training programs is result of institutional forces, it may be suggested that organization try to enhance their legitimacy. In this section, we discuss the most noteworthy results and their implications for practice and future research. We introduce new perspective by taking into considerations the importance of institutional factors in determining the decision of social enterprises toward training programs. So far, human resources management practices were considered only as enhancing resources and improving performance.

This paper has taken into account the funding organization, union, as source of coercive pressure, professional linkages are considered as source of normative pressures, uncertainty in environment and leaders in field as source of mimetic pressures. Our study reveals that training programs are guided by coercive, normative and mimetic pressures and are consistent with preceding studies (Combs, et al., 2009; Farndale \& Paauwe, 2007; Love \& Cebon, 2008; Som, 2007).

The institutional theory posits that organizations are affected by surrounding environment in which they are embedded. It is suggested that social enterprises although considered as autonomous bodies. But still, they are affected by rules and regulations presents in it's surrounding. Previous studies have also shown that effect of environment on nonprofit organizations and social enterprises in some ways e.g. ICT adoption by non profits. Results suggested that coercive pressures from the funding organizations and union tends to affect adoption process, explanation to this hypothesis 1 can be given as funding organizations demand their funds to be used in enhancing creativity of organizations and improve management system of social enterprises. For hypothesis 2, those social enterprises that are more involved in different associations or collaborations, have more pressures to develop training programs for its workforce. The networks of professionals are considered as mean of normative pressures. As a result of more associations or collaborations, the social enterprise tries to maintain better its standard and reputation. They try to gain quality certificate which make them more reliable. As explanation for hypothesis 3 can be suggested that in Pakistan most of social enterprises are at starting of their life cycle and they are not properly recognized, so for hypothesis 3 it is suggested that social enterprises follow the leading organizations because in beginning they strive to avoid doing experiment, which will be difficult in preliminary stage of their life cycle.

This study demonstrates positive link between adoption of human resource practice e.g. training of managers with legitimacy, which is in agreement with the institutional theory, which posit that organization adopt different practices not only to improve the efficiency but also to be socially accepted (John W. Meyer \& Rowan, 1977; Rao, Greve, \& Davis, 2001; Suchman, 1995) (Dickson \& Weaver, 2008). It can be suggested that social enterprise not 
only train their managers to improve performance but also trend to be acceptable by values and norms in society. Our study support the idea of institutional theory, which state that those organizations that are legitimized by their surroundings ensure their survival (Paul J. DiMaggio \& Powell, 1983; John W. Meyer \& Rowan, 1977). In order to attain legitimacy organization accept the pressure from various actors, trends to get approval from those actors to improve the outcomes (Joel \& Oliver, 1991). Our final hypothesis suggests that by executing training program social enterprises can improve their performance. It is because when the managers in social enterprises are efficiently trained which makes them capable of actively finding donors, volunteers and communicates with people and exploits those ideas that can attract general public and solve predicament. Training of managers may also facilitate to improve products and services provided by social enterprises. Training has influenced performance of social enterprises in many ways. Training programs help to improve the skills, which consecutively help to decrease dissatisfaction and improve job satisfaction (Huselid, et al., 1997). Training programs lessen the risk of selecting and hiring new workforce again and again, hence training of current workforce is easy for organization rather than hiring new personal. It may develop commitments of workforce with organization and identification of employees (Mufti, Xiaobao, Shah, Sarwar, \& Zhenqing, 2019). Social enterprises faces various challenges which results in acute pressures on management, to acquire various skills to tackle challenges. Therefore the training programs for enhancement of skills are necessary to attain the better performance. It is clear from previous literature that organizations implement development programs for their managers is of critical importance for progress in performance (Butler, et al., 1991; Schuler \& Jackson, 1987). Our final hypothesis is summarized that developing training programs can potentially make a difference in the performance of a social enterprise. This study strongly emphasizes the development of training programs for both current and newly appointed workforce, as training programs result in enhancement of skills and capabilities, which have the vast influence of the employee performance, commitment, working place climate. Training programs enhance the external legitimacy of ventures; these programs formulate social ventures that have a fine reputation and relations among the other members, training programs also increase the media coverage and most important cause acceptance in society. These external and internal benefits of training should be taken into account while making strategies regarding the management. Senior management in social ventures is suggested to critically analyze the outside environment while deciding between the adoption of training programs. It is suggested that management should take a clear view of all factors, which can influence the long terms success of ventures. Along with the importance of training programs in social enterprises, it's been advised that training programs should be designed per needs, core mission, and policy of organizations.

Social enterprises are considered as an innovative solution provider, as innovation is a basic component in the success of social enterprises. Innovation is a combination to develop in a new way to existing knowledge and information, hence this requires extensive knowledge to understand and make use of the existing knowledge. To enhance the performance of the social enterprises it is necessary to provoke continuous learning and training, which causes an 
increase in new knowledge and persuades the workforce to do an experiment and find an innovative solution at their workplace.

\section{Practical implications and Limitations}

Concerning the formerly mentioned understandings of the results, several caveats required to be noted concerning the present study. This study is based on cross-sectional data; using data to test our hypotheses cannot give a clear picture of long term efforts of training programs in social enterprises and their effects in the long run. Long term effects of training, different methods of training on performance, and examining performance before and after training programs should be explored to further extend the research. The preliminary nature of this research evokes replication to other geographic areas and by using a larger sample size. The questionnaire is filled by the same respondents may be subjected to bias into the finding, in the sense that the influence of pressure on legitimacy may have been hyped and this factor may affect the generalizability of the research. This research follows a quantitative approach further studies may combine both quantitative and qualitative to better understand other key aspects.

Similar to the institutional approach, this study confirms the training of managers improve performance and enhance external and internal legitimacy. Social enterprises should make some arrangement and programs which help the employee to get familiar with both the social and financial goal of a social venture. This study strongly emphasizes the development of training programs for both current and newly appointed workforce, as training programs result in enhancement of skills and capabilities, which have a vast influence on employee performance, commitment, working place climate. Training programs enhance the internal legitimacy; by improving the work climate, employees feel committed, and as an employee have a feeling of identification which makes them satisfy. These internal benefits of training should be taken into consideration while making strategies regarding the management. Our findings have potential implications for managers and social enterprise management system, our research shows the importance of training to gain the acceptably both internally and externally. Training not only enhance knowledge but also improve skills needed to tackle the wide range of problems, training also adds positive value as it is endorsed by the workforce, partners, and society as a whole. The above-mentioned recommendations are of critical importance for the senior's management in social enterprises, as it forms the bases and noteworthy steps for improved outcomes of social enterprises.

This study contributes to the limited research on the training programs adoptions in social enterprises, by presenting a comprehensive exploration of training programs adoption and assessing institutional pressures that lead to the adoption of training programs. This study provides a more complex picture related to the adoption of training and its effect or role played in organizational attainment of legitimacy and performance. This study will create an understanding regarding training programs and will provoke social enterprises to take steps to enhance their outcomes. Our study plays its important part as the results would help in promoting social enterprise to initiate training programs and will provoke them to gain legitimacy and improve performance. 


\section{References}

AbouAssi, K., \& Bies, A. (2018). Relationships and resources: the isomorphism of nonprofit organizations'(NPO) self-regulation. Public Management Review, 20(11), 1581-1601.

Ahmad, S., \& Schroeder, R. G. (2003). The impact of human resource management practices on operational performance: recognizing country and industry differences. Journal of Operations Management, 21(1), 19-43. https://doi.org/10.1016/S0272-6963(02)00056-6

Al-Dhaafri Hassan, S. (2016). The mediating role of total quality management between the entrepreneurial orientation and the organizational performance. The TQM Journal, 28(1), 89-111. https://doi.org/10.1108/TQM-03-2014-0033

Amini, Z., Arasti, Z., \& Bagheri, A. (2018). Identifying social entrepreneurship competencies of managers in social entrepreneurship organizations in healthcare sector. Journal of Global Entrepreneurship Research, 8(1), 19. https://doi.org/10.1186/s40497-018-0102-x

Araujo de la Mata, A., Barrutia Güenaga, J., Hoyos Iruarrizaga, J., Landeta Rodríguez, J., \& Ibáñez Hernández, F. J. (2006). Behavior of companies regarding the continuous training of their managers.

Austin, J. E. (2006). Three Avenues for Social Entrepreneurship Research. In J. Mair, J. Robinson \& K. Hockerts (Eds.), Social Entrepreneurship (pp. 22-33). London: Palgrave Macmillan UK.

Barney, J. (1991). Firm Resources and Sustained Competitive Advantage. Journal of Management, 17(1), 99-120. https://doi.org/10.1177/014920639101700108

Barrett, A., \& O'Connell, P. J. (2001). Does Training Generally Work? The Returns to in-Company Training. ILR Review, 54(3), 647-662. https://doi.org/10.1177/001979390105400307

Battilana, J., \& Dorado, S. (2010). Building Sustainable Hybrid Organizations: The Case of Commercial Microfinance Organizations. Academy of Management Journal, 53(6), 1419-1440. https://doi.org/10.5465/amj.2010.57318391

Battilana, J., \& Lee, M. (2014). Advancing Research on Hybrid Organizing - Insights from the Study of Social Enterprises. The Academy of Management Annals, 8(1), 397-441. https://doi.org/10.1080/19416520.2014.893615

Bird, B. (1995). Toward a Theory of Entrepreneurial Competency In: Katz JA and Brockhaus RH (eds) Advances in Entrepreneurship, Firm Emergence and Growth: Greenwich: Jai Press Inc.

Bitektine, A. (2011). Toward a Theory of Social Judgments of Organizations: The Case of Legitimacy, Reputation, and Status. Academy of Management Review, 36(1), 151-179. https://doi.org/10.5465/amr.2009.0382

Booth, A. L., Francesconi, M., \& Zoega, G. (2003). Unions, Work-Related Training, and Wages: Evidence for British Men. ILR Review, 57(1), 68-91. 
https://doi.org/10.1177/001979390305700104

Borst, R. T., Kruyen, P. M., \& Lako, C. J. (2017). Exploring the Job Demands-Resources Model of Work Engagement in Government: Bringing in a Psychological Perspective. Review of Public Personnel Administration, $\quad 0(0), \quad 0734371 X 17729870$. https://doi.org/10.1177/0734371x17729870

Boyatzis, R. E., \& Saatcioglu, A. (2008). A 20-year view of trying to develop emotional, social and cognitive intelligence competencies in graduate management education. Journal of Management Development, 27(1), 92-108. https://doi.org/10.1108/02621710810840785

Boyatzis, R. E., Stubbs, E. C., \& Taylor, S. N. (2002). Learning Cognitive and Emotional Intelligence Competencies Through Graduate Management Education. Academy of $\begin{array}{llll}\text { Management Learning } \quad \& \quad \text { Education, } & 1(2),\end{array}$ https://doi.org/10.5465/amle.2002.8509345

Brandes, P., Hadani, M., \& Goranova, M. (2006). Stock options expensing: An examination of agency and institutional theory explanations. Journal of Business Research, 59(5), 595-603. https://doi.org/10.1016/j.jbusres.2005.09.018

Brown, A. D., \& Toyoki, S. (2013). Identity Work and Legitimacy. Organization Studies, 34(7), 875-896. https://doi.org/10.1177/0170840612467158

Budhwar, P. S., \& Sparrow, P. R. (2002). An integrative framework for understanding cross-national human resource management practices. Human Resource Management Review, 12(3), 377-403. https://doi.org/10.1016/S1053-4822(02)00066-9

Butler, J., Ferris, G., \& Napier, N. (1991). Strategy and Human Resource Management (Cincinnati, OH, South-Western).

Cashore, B., \& Vertinsky, I. (2000). Policy networks and firm behaviours: Governance systems and firm reponses to external demands for sustainable forest management. [journal article]. Policy Sciences, 33(1), 1-30. https://doi.org/10.1023/a:1004728206505

Certo, S. T., \& Hodge, F. (2007). Top Management Team Prestige and Organizational Legitimacy: An Examination of Investor Perceptions. Journal of Managerial Issues, 19(4), 461-477.

Comacchio, A., \& Scapolan, A. (2004). The adoption process of corporate e-learning in Italy. Education + Training, 46(6/7), 315-325. https://doi.org/10.1108/00400910410555222

Combs, J. G., Michael, S. C., \& Castrogiovanni, G. J. (2009). Institutional Influences on the Choice of Organizational Form: The Case of Franchising. Journal of Management, 35(5), 1268-1290. https://doi.org/10.1177/0149206309336883

Connolly, C., \& Kelly, M. (2011). Understanding accountability in social enterprise organisations: a framework. Social Enterprise Journal, 7(3), 224-237. https://doi.org/10.1108/17508611111182386

Cordery, C., \& Sinclair, R. (2013). Measuring performance in the third sector. Qualitative 


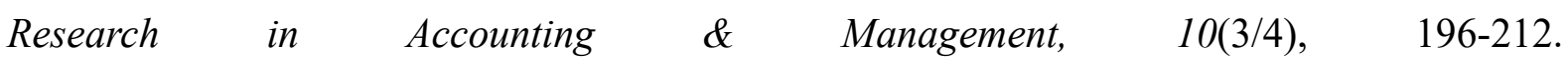
https://doi.org/10.1108/QRAM-03-2013-0014

Dacin, M. T., Dacin, P. A., \& Tracey, P. (2011). Social Entrepreneurship: A Critique and Future Directions. Organization Science, 22(5), 1203-1213. https://doi.org/10.1287/orsc.1100.0620

Dacin, M. T., Oliver, C., \& Roy, J.-P. (2007). The legitimacy of strategic alliances: an institutional perspective. Strategic Management Journal, 28(2), 169-187. https://doi.org/10.1002/smj.577

Dasgupta, S., Hettige, H., \& Wheeler, D. (2000). What Improves Environmental Compliance? Evidence from Mexican Industry. Journal of Environmental Economics and Management, 39(1), 39-66. https://doi.org/10.1006/jeem.1999.1090

Davidsson, P. (2005). Methodological Approaches to Entrepreneurship: Past Research and Suggestions for the Future. Small Enterprise Research, 13(1), 1-21. https://doi.org/10.5172/ser.13.1.1

Davis, J. A., Marino, L. D., Aaron, J. R., \& Tolbert, C. L. (2011). An Examination of Entrepreneurial Orientation, Environmental Scanning, and Market Strategies of Nonprofit and For-Profit Nursing Home Administrators. Nonprofit and Voluntary Sector Quarterly, 40(1), 197-211. https://doi.org/10.1177/0899764009351112

Defourny, J., \& Nyssens, M. (2006). Social enterprise: at the crossroads of market, public policies and civil society. Routledge, London, 3-26.

Delmas, M., \& Toffel, M. W. (2004). Stakeholders and environmental management practices: an institutional framework. Business Strategy and the Environment, 13(4), 209-222. https://doi.org/10.1002/bse.409

Dickson, P. H., \& Weaver, K. M. (2008). The role of the institutional environment in determining firm orientations towards entrepreneurial behavior. [journal article]. International Entrepreneurship and Management Journal, 4(4), 467-483. https://doi.org/10.1007/s11365-008-0088-x

DiMaggio, P. J., \& Powell, W. W. (1983). The Iron Cage Revisited: Institutional Isomorphism and Collective Rationality in Organizational Fields. American Sociological Review, 48(2), 147-160. https://doi.org/10.2307/2095101

DiMaggio, P. J., \& Powell, W. W. (1991). Introduction. The new institutionalism in organizational analysis. The New Institutionalism in Organizational Analysis, University of Chicago Press, Chicago, IL, 1-38.

Doherty, B., Haugh, H., \& Lyon, F. (2014). Social Enterprises as Hybrid Organizations: A Review and Research Agenda. International Journal of Management Reviews, 16(4), 417-436. https://doi.org/10.1111/ijmr.12028

Drori, I., \& Honig, B. (2013). A Process Model of Internal and External Legitimacy. 
Organization Studies, 34(3), 345-376. https://doi.org/10.1177/0170840612467153

Esteban-Lloret, N. N., Aragón-Sánchez, A., \& Carrasco-Hernández, A. (2018). Determinants of employee training: impact on organizational legitimacy and organizational performance. The International Journal of Human Resource Management, 29(6), 1208-1229. https://doi.org/10.1080/09585192.2016.1256337

Farndale, E., \& Brewster, C. (2005). In search of legitimacy: personnel management associations worldwide. Human Resource Management Journal, 15(3), 33-48. https://doi.org/10.1111/j.1748-8583.2005.tb00152.x

Farndale, E., \& Paauwe, J. (2007). Uncovering competitive and institutional drivers of HRM practices in multinational corporations. Human Resource Management Journal, 17(4), 355-375. https://doi.org/10.1111/j.1748-8583.2007.00050.x

Fornell, C., \& Larcker, D. F. (1981). Evaluating structural equation models with unobservable variables and measurement error. Journal of marketing research, 39-50. https://doi.org/10.2307/3151312

Frambach, R. T., \& Schillewaert, N. (2002). Organizational innovation adoption: a multi-level framework of determinants and opportunities for future research. Journal of Business Research, 55(2), 163-176. https://doi.org/10.1016/S0148-2963(00)00152-1

Ghebregiorgis, F., \& Karsten, L. (2007). Human resource management and performance in a developing country: the case of Eritrea. The International Journal of Human Resource Management, 18(2), 321-332. https://doi.org/10.1080/09585190601102547

Gonin, M., Besharov, M. H. P., \& Smith, W. K. (2013). Managing Social-Business Tensions: A Review and Research Agenda for Social Enterprises. Academy of Management Proceedings, 2013(1), 11745. https://doi.org/10.5465/ambpp.2013.187

Green, F., Machin, S., \& Wilkinson, D. (1999). Trade Unions and Training Practices in British Workplaces. ILR Review, 52(2), 179-195. https://doi.org/10.1177/001979399905200202

Greenwood, R., Suddaby, R., \& Hinings, C. R. (2002). Theorizing Change: The Role of Professional Associations in the Transformation of Institutionalized Fields. Academy of Management Journal, 45(1), 58-80. https://doi.org/10.5465/3069285

Guler, I., Guillén, M. F., \& Macpherson, J. M. (2002). Global Competition, Institutions, and the Diffusion of Organizational Practices: The International Spread of ISO 9000 Quality Certificates. Administrative Science Quarterly, 47(2), 207-232. https://doi.org/10.2307/3094804

Gupta, V., MacMillan, I. C., \& Surie, G. (2004). Entrepreneurial leadership: developing and measuring a cross-cultural construct. Journal of Business Venturing, 19(2), 241-260. https://doi.org/10.1016/S0883-9026(03)00040-5

Hair, J. F., Hult, G. T. M., Ringle, C., \& Sarstedt, M. (2016). A Primer on Partial Least 
Squares Structural Equation Modeling (PLS-SEM): SAGE Publications.

Hair, J. F., Hult, G. T. M., Ringle, C. M., Sarstedt, M., \& Thiele, K. O. (2017). Mirror, mirror on the wall: a comparative evaluation of composite-based structural equation modeling methods. Journal of the Academy of Marketing Science, 45(5), 616-632. https://doi.org/10.1007/s11747-017-0517-x

Hair, J. F., Ringle, C. M., \& Sarstedt, M. (2013). Partial least squares structural equation modeling: Rigorous applications, better results and higher acceptance. Long range planning, 46(1-2), 1-12.

Harman, G., \& Harman, K. (2008). Strategic Mergers of Strong Institutions to Enhance Competitive Advantage. [journal article]. Higher Education Policy, 21(1), 99-121. https://doi.org/10.1057/palgrave.hep.8300172

Henseler, J. (2009). The use of partial least squares path modeling in international marketing. In M. Ringle Christian, R. S. Rudolf \& N. G. Pervez (Eds.), New Challenges to International Marketing (Vol. 20, pp. 277-319): Emerald Group Publishing Limited.

Hofman, P. S., Li, L., Sun, S. L., \& Sun, Y. (2019). Institutional drivers of stakeholder engagement and legitimacy of Chinese MNEs Socially Responsible International Business: Edward Elgar Publishing.

Honig, B., \& Karlsson, T. (2004). Institutional forces and the written business plan. Journal of Management, 30(1), 29-48. https://doi.org/10.1016/j.jm.2002.11.002

Huang, L. C. (2017). Factors affecting creativity in information system development. Industrial Management \&amp; Data Systems, 117(3), 496-520. https://doi.org/10.1108/IMDS-08-2015-0335

Huselid, M. A., Jackson, S. E., \& Schuler, R. S. (1997). Technical and Strategic Human Resources Management Effectiveness as Determinants of Firm Performance. Academy of Management Journal, 40(1), 171-188. https://doi.org/10.5465/257025

Hussmanns, R. (2004). Measuring the informal economy: From employment in the informal sector to informal employment: Policy Integration Department, Bureau of Statistics, International Labour Office.

ILO. (2011). Statistical update on employment in the informal economy. Geneva: ILO Department of Statistics; .

Inoue, Y., \& Lee, S. (2011). Effects of different dimensions of corporate social responsibility on corporate financial performance in tourism-related industries. Tourism Management, 32(4), 790-804. https://doi.org/10.1016/j.tourman.2010.06.019

Jerez Gómez, P., Céspedes Lorente, J. J., \& Valle Cabrera, R. (2004). Training practices and organisational learning capability: Relationship and implications. Journal of European Industrial Training, 28(2/3/4), 234-256. https://doi.org/10.1108/03090590410527636

Joel, A. C. B., \& Oliver, C. (1991). Institutional Linkages and Organizational Mortality. 
Administrative Science Quarterly, 36(2), 187-218. https://doi.org/10.2307/2393353

Kandola, R. S., \& Fullerton, J. (1998). Diversity in action: Managing the mosaic: CIPD Publishing.

Kaufman, R., Avgar, A., \& Mirsky, J. (2007). Social Entrepreneurship in Crisis Situations. International Journal of Diversity in Organisations, Communities \& Nations, 7(3).

Khalifa, M., \& Davison, M. (2006). SME adoption of IT: the case of electronic trading systems. IEEE Transactions on Engineering Management, 53(2), 275-284. https://doi.org/10.1109/tem.2006.872251

Khanna, M., \& Damon, L. A. (1999). EPA's Voluntary 33/50 Program: Impact on Toxic Releases and Economic Performance of Firms. Journal of Environmental Economics and Management, 37(1), 1-25. https://doi.org/10.1006/jeem.1998.1057

Kibler, E., Salmivaara, V., Stenholm, P., \& Terjesen, S. (2018). The evaluative legitimacy of social entrepreneurship in capitalist welfare systems. Journal of World Business, 53(6), 944-957. https://doi.org/10.1016/j.jwb.2018.08.002

Kline, R. B. (2015). Principles and Practice of Structural Equation Modeling, Fourth Edition: Guilford Publications.

Kostova, T., \& Roth, K. (2002). Adoption of an Organizational Practice by Subsidiaries of Multinational Corporations: Institutional and Relational Effects. Academy of Management Journal, 45(1), 215-233. https://doi.org/10.5465/3069293

Kostova, T., \& Zaheer, S. (1999). Organizational Legitimacy Under Conditions of Complexity: The Case of the Multinational Enterprise. Academy of Management Review, 24(1), 64-81. https://doi.org/10.5465/amr.1999.1580441

Kreiser, P. M., Marino, L. D., Dickson, P., \& Weaver, K. M. (2010). Cultural Influences on Entrepreneurial Orientation: The Impact of National Culture on Risk Taking and Proactiveness in SMEs. Entrepreneurship Theory and Practice, 34(5), 959-984. https://doi.org/10.1111/j.1540-6520.2010.00396.x

Kuosmanen, J. (2014). Care Provision, Empowerment, and Market Forces: The Art of Establishing Legitimacy for Work Integration Social Enterprises (WISEs). International Journal of Voluntary and Nonprofit Organizations, 25(1), 248-269. https://doi.org/10.1007/s11266-012-9340-7

Kuzilwa, J. A. (2005). The Role of Credit for Small Business Success:A Study of the National Entrepreneurship Development Fund in Tanzania. The Journal of Entrepreneurship, 14(2), 131-161. https://doi.org/10.1177/097135570501400204

Lazear, E. P. (2004). Balanced Skills and Entrepreneurship. American Economic Review, 94(2), 208-211. https://doi.org/10.1257/0002828041301425

Lewis, P. (2006). The Quest for Invisibility: Female Entrepreneurs and the Masculine Norm of Entrepreneurship. Gender, Work \& Organization, 13(5), 453-469. 
https://doi.org/10.1111/j.1468-0432.2006.00317.x

Liu, G., Eng, T. Y., \& Takeda, S. (2015). An Investigation of Marketing Capabilities and Social Enterprise Performance in the UK and Japan. Entrepreneurship Theory and Practice, 39(2), 267-298. https://doi.org/10.1111/etap.12041

Love, E. G., \& Cebon, P. (2008). Meanings on Multiple Levels: The Influence of Field-Level and Organizational-Level Meaning Systems on Diffusion. Journal of Management Studies, 45(2), 239-267. https://doi.org/10.1111/j.1467-6486.2007.00739.x

Lyon, F., \& Ramsden, M. (2006). Developing fledgling social enterprises? A study of the support required and means of delivering it. Social Enterprise Journal, (2).

Mabey, C. (2004). Developing Managers in Europe: Policies, Practices, and Impact. Advances in Developing Human Resources, 6(4), 404-427. https://doi.org/10.1177/1523422304268380

Mair, J., \& Hehenberger, L. (2014). Front-Stage and Backstage Convening: The Transition from Opposition to Mutualistic Coexistence in Organizational Philanthropy. Academy of Management Journal, 57(4), 1174-1200. https://doi.org/10.5465/amj.2012.0305

Martínez-Ferrero, J., \& García-Sánchez, I.-M. (2017). Coercive, normative and mimetic isomorphism as determinants of the voluntary assurance of sustainability reports. International Business Review, 26(1), 102-118.

Meyer, J. W. (1983). Centralization and the legitimacy problems of local government. Organizational environments: Ritual and rationality.

Meyer, J. W., \& Rowan, B. (1977). Institutionalized Organizations: Formal Structure as Myth and Ceremony. American Journal of Sociology, 83(2), 340-363. https://doi.org/10.1086/226550

Morris, M. H., \& Jones, F. F. (1993). Human resource management practices and corporate entrepreneurship: an empirical assessment from the USA. The International Journal of Human Resource Management, 4(4), 873-896. https://doi.org/10.1080/09585199300000062

Mufti, M., Xiaobao, P., Shah, S. J., Sarwar, A., \& Zhenqing, Y. (2019). Influence of leadership style on job satisfaction of NGO employee: The mediating role of psychological empowerment. Journal of Public Affairs, e1983. https://doi.org/10.1002/pa.1983

Nikandrou, I., Apospori, E., Panayotopoulou, L., Stavrou, E. T., \& Papalexandris, N. (2008). Training and firm performance in Europe: the impact of national and organizational characteristics. The International Journal of Human Resource Management, 19(11), 2057-2078. https://doi.org/10.1080/09585190802404304

Osterman, P. (1994). How Common is Workplace Transformation and Who Adopts it? ILR Review, 47(2), 173-188. https://doi.org/10.1177/001979399404700202

Paauwe, J. (2004). HRM and performance: Achieving long-term viability: Oxford University Press on Demand. 
Paauwe, J., \& Boselie, P. (2003). Challenging 'strategic HRM' and the relevance of the institutional setting. Human Resource Management Journal, 13(3), 56-70. https://doi.org/10.1111/j.1748-8583.2003.tb00098.x

Pache, A. C., \& Santos, F. (2010). When Worlds Collide: The Internal Dynamics of Organizational Responses to Conflicting Institutional Demands. Academy of Management Review, 35(3), 455-476. https://doi.org/10.5465/amr.35.3.zok455

Palmer, D., \& Biggart, N. (2002). Organizational İnstitutions. Baum JAC, Der.) The Blackwell Companion to Organizations: Blackwell, Oxford.

Pasamar Reyes, S., \& Valle Cabrera, R. (2011). Presiones institucionales para la conciliación de la vida profesional y personal. Cuadernos de Economía y Dirección de la Empresa, 14(4), 258-268. https://doi.org/10.1016/j.cede.2011.02.010

Pearce, J. A., Fritz, D. A., \& Davis, P. S. (2010). Entrepreneurial Orientation and the Performance of Religious Congregations as Predicted by Rational Choice Theory. Entrepreneurship Theory and Practice, 34(1), 219-248. https://doi.org/10.1111/j.1540-6520.2009.00315.x

Penrose, E., \& Penrose, E. T. (2009). The Theory of the Growth of the Firm: Oxford university press.

Podsakoff, P. M., MacKenzie, S. B., Lee, J. Y., \& Podsakoff, N. P. (2003). Common method biases in behavioral research: A critical review of the literature and recommended remedies. Journal of Applied Psychology, 88(5), 879-903. https://doi.org/10.1037/0021-9010.88.5.879

Preacher, K. J., \& Hayes, A. F. (2008). Asymptotic and resampling strategies for assessing and comparing indirect effects in multiple mediator models.. Behavior Research Methods, 40(3), 879-891. https://doi.org/10.3758/brm.40.3.879

Rao, H., Greve, H. R., \& Davis, G. F. (2001). Fool's Gold: Social Proof in the Initiation and Abandonment of Coverage by Wall Street Analysts. Administrative Science Quarterly, 46(3), 502-526. https://doi.org/10.2307/3094873

Rezaei, S., Shahijan, M. K., Valaei, N., Rahimi, R., \& Ismail, W. K. W. (2016). Experienced international business traveller's behaviour in Iran: A partial least squares path modelling analysis. Tourism and Hospitality Research, 18(2), 163-190. https://doi.org/10.1177/1467358416636930

Ruef, M., \& Scott, W. R. (1998). A Multidimensional Model of Organizational Legitimacy: Hospital Survival in Changing Institutional Environments. Administrative Science Quarterly, 43(4), 877-904. https://doi.org/10.2307/2393619

Schuler, R. S., \& Jackson, S. E. (1987). Organizational Strategy and Organization Level as Determinants of Human Resource Management Practices. [Article]. Human Resource Planning, 10(3), 125-142.

Scott, W. R. (2008). Institutions and organizations: Ideas and interests: Sage. 
Scott, W. R. (2013). Institutions and organizations: Ideas, interests, and identities: Sage Publications.

Shah, S. J., Zhang, L., Khan, S., Shah, S. A. A., Durrani, D. K., Ali, L., \& Das, B. (2018). Terrorism vulnerability: organizations' ambiguous expectations and employees' conflicting priorities. International Journal of Occupational Safety and Ergonomics, 1-11. https://doi.org/10.1080/10803548.2018.1486056

Shaw, E., \& de Bruin, A. (2013). Reconsidering capitalism: the promise of social innovation and social entrepreneurship? International Small Business Journal, 31(7), 737-746. https://doi.org/10.1177/0266242613497494

Shonk, D. J., \& Bravo, G. (2010). Interorganizational Support and Commitment: A Framework for Sporting Event Networks. Journal of Sport Management, 24(3), 272-290. https://doi.org/10.1123/jsm.24.3.272

Som, A. (2007). What drives adoption of innovative SHRM practices in Indian organizations? The International Journal of Human Resource Management, 18(5), 808-828. https://doi.org/10.1080/09585190701248695

Spector, P. E., Fox, S., Penney, L. M., Bruursema, K., Goh, A., \& Kessler, S. (2006). The dimensionality of counterproductivity: Are all counterproductive behaviors created equal? Journal of Vocational Behavior, 68(3), 446-460. https://doi.org/10.1016/j.jvb.2005.10.005

Suchman, M. C. (1995). Managing Legitimacy: Strategic and Institutional Approaches. Academy of Management Review, 20(3), 571-610. https://doi.org/10.5465/amr.1995.9508080331

Sud, M., VanSandt, C. V., \& Baugous, A. M. (2009). Social Entrepreneurship: The Role of Institutions. [journal article]. Journal of Business Ethics, 85(1), 201-216. https://doi.org/10.1007/s10551-008-9939-1

Suddaby, R., Bitektine, A., \& Haack, P. (2017). Legitimacy. Academy of Management Annals, 11(1), 451-478. https://doi.org/10.5465/annals.2015.0101

Suddaby, R., \& Greenwood, R. (2005). Rhetorical Strategies of Legitimacy. Administrative Science Quarterly, 50(1), 35-67. https://doi.org/10.2189/asqu.2005.50.1.35

Teo, H. H., Wei, K. K., \& Benbasat, I. (2003). Predicting Intention to Adopt Interorganizational Linkages: An Institutional Perspective. MIS Quarterly, 27(1), 19-49. https://doi.org/10.2307/30036518

Thomas, T. E. (2005). Are business students buying it? A theoretical framework for measuring attitudes toward the legitimacy of environmental sustainability. Business Strategy and the Environment, 14(3), 186-197. https://doi.org/10.1002/bse.446

Tolbert, P., \& Hall, R. (2009). Organizations: Structures. Processes, and Outcomes (10th.

Tracey, P., Phillips, N., \& Jarvis, O. (2011). Bridging Institutional Entrepreneurship and the Creation of New Organizational Forms: A Multilevel Model. Organization Science, 22(1), 


\section{Macrothink \\ Journal of Entrepreneurship and Business Innovation \\ ISSN 2332-8851 2020, Vol. 7, No. 1}

60-80. https://doi.org/10.1287/orsc.1090.0522

Vlachos, I. (2008). The effect of human resource practices on organizational performance: evidence from Greece. The International Journal of Human Resource Management, 19(1), 74-97. https://doi.org/10.1080/09585190701763933

Westphal, J. D., Gulati, R., \& Shortell, S. M. (1997). Customization or Conformity? An Institutional and Network Perspective on the Content and Consequences of TQM Adoption. Administrative Science Quarterly, 42(2), 366-394. https://doi.org/10.2307/2393924

Wiklund, J., \& Shepherd, D. (2005). Entrepreneurial orientation and small business performance: a configurational approach. Journal of Business Venturing, 20(1), 71-91. https://doi.org/10.1016/j.jbusvent.2004.01.001

Yang, Y., \& Konrad, A. M. (2011). Understanding Diversity Management Practices: Implications of Institutional Theory and Resource-Based Theory. Group \& Organization Management, 36(1), 6-38. https://doi.org/10.1177/1059601110390997

Zimmerman, M. A., \& Zeitz, G. J. (2002). Beyond Survival: Achieving New Venture Growth by Building Legitimacy. Academy of Management Review, 27(3), 414-431. https://doi.org/10.5465/amr.2002.7389921

\section{Copyright Disclaimer}

Copyright for this article is retained by the author (s), with first publication rights granted to the journal.

This is an open-access article distributed under the terms and conditions of the Creative Commons Attribution license (http://creativecommons.org/licenses/by/3.0/). 